benefits and challenges presented by US law and offer the reader the opportunity to appreciate these differences.

As the online environment continues to offer opportunities and challenges for higher education, new publications that consider copyright implications are a welcome resource for professionals tasked with supporting the missions of their academic institutions. Whether navigating and advising on copyright is one's primary role or if copyright law influences one's work, Copyright Conversations: Rights Literacy in a Digital World is a valuable text to have on hand on your bookshelf or in your library.-Janis L. DesMarais, College of the Holy Cross

Archival Values: Essays in Honor of Mark A. Greene. Christine Weideman and Mary A. Caldera, eds. Chicago, IL: American Library Association, 2019. 300p. Paper, $\$ 55.99$ (ISBN 9780838946503).

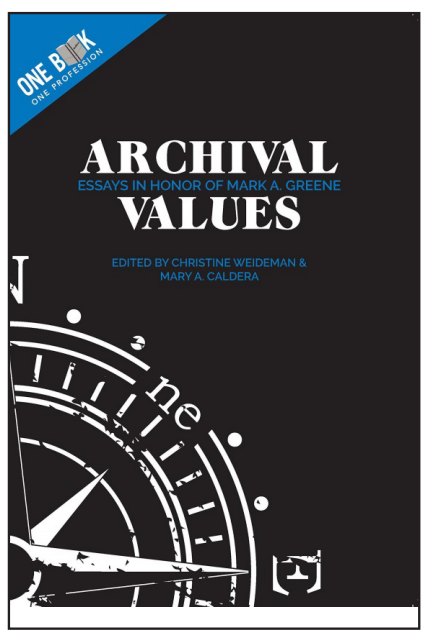

How might a book review - or a book itself for that matter-change in scope or meaning if its readers are under quarantine? For those of us living in an altered state due to the COVID-19 public health crisis, nothing is as it was. So why should reading and reviewing a book like Archival Values: Essays in Honor of Mark A. Greene be any different? When libraries, archives, historical societies, and college classrooms closed to the public to slow the spread of a deadly disease, many archivists and librarians went into exile. Our reading rooms and our researchers, our collections and our facilities, were off limits. For some of us, our very livelihoods are at risk (or worse, were laid waste) by these closures. What would Mark Greene have said? What would he have done? And for those who don't yet know who Mark Greene was, why do his archival values matter? And why now?

Some clues can be found by way of this volume's thoughtful introduction and its afterword, written by prominent archivists who called Mark Greene a colleague, collaborator, and friend. Greene, to whom this book serves as a memorial, died in a car accident in 2017. He was a prolific and influential archivist, teacher, administrator, and thinker, perhaps best known as co-creator and advocate of the "More Product, Less Process" approach to tackling archival backlogs. Greene also authored or co-authored nearly 30 articles, delivered as many conference papers, and served at all levels of the archival profession. It was as president of the Society of American Archivists (SAA) that Greene first theorized a core set of values to help define and guide the work - and the collective identities - of American archivists. Each of the 23 essays in this volume take one of these values as a starting point and, in so doing, breathe life into them, animating each value with a deep sense of public service and professionalism.

The two dozen authors come from a dizzying array of institutions, both in size and reach, and their professional experiences range from two to more than 30 years. The breadth of institutional settings and expertise creates something of a paratextual community. That is to say, for readers recently displaced from their own archives, each of the book's 11 sections invites us to join one house party after another. Made up of two or three essays, each addressing one of Greene's archival values, a reader could theoretically pop in and out, sampling across these sections based on their immediate need. What is your most pressing professional dilemma: access and use, preservation, advocacy? Or, like me, you might choose to linger at every party, even overstaying your welcome at a few. If you were to do so, you would be rewarded with 
diverse, sometimes startlingly timely essays that speak not only to badge-carrying archivists but also to the constellation of staff and professionals who work side by side with them. These include special collections and instruction librarians, historians, and an untold number of essential staff, interns, and volunteers. These allied laborers may not call themselves archivists, yet they sustain and champion archives with equal zeal.

The official version of the SAA Core Values, included as an appendix, is probably accessed online by most of us. In both of those locations (that is, in this appendix and online), Greene's values are listed alphabetically, famously starting with "access" and ending in "social responsibility." The editors explain why they organized things differently. Rather than march lock-step through the alphabetical list, Christine Weideman and Mary Caldera describe their ordering as being true to Mark Greene's life's work. He wrestled with the big questions: why are we here; what do we do; and how do we do it. The first essay, by Jennifer Meehan, starts the anthology with a rousing essay, "Archival Tangibles: Empowerment Through Story and Meaning." She calls on archivists to practice "radical openness, hospitality, and power sharing," in order to "create a more inclusive historical record" and "foster a sense of belonging among marginalized individuals and communities." There could be no more timely call to action.

Even the seemingly technical and procedural sections transcend the standard how-to manual. Take, for example, a section like "On Preservation" with two essays, one by Rachel Onuf and another by Ben Goldman. Onuf takes a long, penetrating view of the ups and downs dogging preservation theories and practices, while leaving us with clear-eyed sentiments guiding best practices for large and small institutions. If Onuf's essay offers a guiding yet firm hand, "It's Not Easy Being Green(e): Digital Preservation in the Age of Climate Change," Goldman's preceding essay, is a cruel shiv straight to the heart of every archivist and librarian who devotes themselves to digital preservation. Our swelling digital collections, Goldman notes, are implicated in the very fossil fuels responsible for ravaging our planet. What would Mark Greene say? This review won't deliver any spoilers, except to say that the usefulness of our libraries and archival collections, and our collective futures, relies on the answer. So the 23 essays in this volume march on, ricocheting between advice, theory, and practice. There are many standouts: the deeply researched and extensive footnotes following essays by Hillel Arnold and Paul Lasewicz alone could make a librarian swoon. And while a few of the essays carry on a little long, nearly all are concise, lively, and deeply relevant, now more than ever.-Rebekah Irwin, Middlebury College

\section{Sustaining and Enhancing the Scholarly Communications Department: A Comprehensive}

Guide. Kris S. Helge, Ahmet Meti Tmava, and Amanda R. Zerangue. Santa Barbara, CA: ABC-CLIO, LLC, 2019. 164p. Paper, \$70.00 (ISBN: 978-1-4408-6699-9). LC 2019031275.

Rarely does a resource speak as candidly and frankly about the experience in the field as Sustaining and Enhancing the Scholarly Communications Department. This volume communicates with the reader like a trusted colleague, anticipating potential questions and interweaving a generosity of wisdom. It also fearlessly leans into forthright conversations on management, a topic less frequently explored and developed in the literature of the discipline.

The authors bring a wealth of knowledge and experience to the volume. Assistant Dean Kris S. Helge leverages administrative experience, a JD, MLS, and PhD in information science, and prior service as a scholarly communications librarian. Ahmet Meti Tmvara, as assistant professor at the School of Library and Information Studies at Texas Woman's University, draws 